\title{
MJN COMPARISON OF LADDER SNAKE AND BUSY BOOK ANDARA ON KNOWLEDGE OF PERSONAL SAFETY SKILLS AGAINST CHILD SEXUAL ABUSE AMONG PRESCHOOL CHILDREN: A QUASI EXPERIMENTAL STUDY
}

\author{
Nurmukaromatis Saleha*, Rina Delfina, Nova Yustisia \\ Department of Maternity Nursing, School of Nursing, Universitas Bengkulu, Indonesia \\ *Corresponding Author's Email: nsaleha@unib.ac.id
}

\begin{abstract}
Background: The high Child Sexual Abuse (CSA) cases occurring in the Bengkulu City needs attention and intensive action. Children need to be provided with knowledge about the rules that is useful as for Personal Safety Skill to protect themselves from risk of child sexual abuse. Aim: the purpose of this study is to compare snake and ladder and busy book Andara in increasing knowledge of personal safety skills (PSS) against child sexual abuse for preschool. Methods: A quasi-experimental with a pretest-posttest control group design was used in this study. One hundred and seven pre-school were divided into two groups, snake and ladder Andara group, and the busy book group. Samples were taken using a simple random sampling technique. Data were analyzed using Wilcoxon and Mann Whitney with SPSS software version 22.0. Results: There was a significant difference in knowledge of PSS between the two groups before and after treatment $(p=0.000)$, and there was a significant difference knowledge of PSS in between the snake and ladder and busy book Andara $(p=0.002)$, with a higher mean rank ladder snake of 62.95. Conclusion: This study demonstrated that there was a significant difference in knowledge of PSS between two groups, and the ladder snake Andara showed better results in increasing knowledge of PSS among preschool compared to the busy book Andara. Recommendation: Development of interactive educational game tools with peers or parents is very important to improve children's knowledge of personal safety skills.
\end{abstract}

Keywords: Ladder Snake Andara; Busy Book Andara; Personal Safety Skills; Child Sexual Abuse; Preschool

\section{INTRODUCTION}

One target of Sustainable Development Indonesia Goals (SDG's) 2030 is to create that a hospitable environment for children. The high sexual violence case against children have become a serious problem in the achievements of the purpose. Protection of children's rights will make a to grow optimally. Children must be fulfilled with their rights well, then only the child will grow into a person with discipline, behave well, and develop responsibility (KPPPA, 2019). An increase in incidents of sexual abuse against children every year have caused Bengkulu city to the declare an emergency against sexual abuse towards children, often enough the cases are accompanied by death. Quoting from online newspaper of September $4^{\text {th }}, 2020$, obtained data, the number of sexual violence cases against children since January to July were as many as 105 cases in the province of Bengkulu and probably increase in Bengkulu City. Sexual violence cases against children are often difficult to handle, this is because they do not occur in the open, no witnesses, and often evidences are not found. Sexual violence against children is difficult to handle because of late reporting also (Purnamawati \& Haryati, (2020).

Slow reporting is due to the nature of the children, as they are highly dependent on adult. This condition makes kids weak and the predator can easily control them, especially if the perpetrator is from the family. 
This makes children confused and reluctant to complain. The ability of perpetrator to overpower the children, either by trickery, as well as threats and violence causing evil is difficult to avoid. Other factors that make the disclosure of this crime difficult, are socioeconomic factors like low education, parenting and technological advances. The regulation on pornography and sexual education inadequate (Arliman, 2017).

In reaction to this, the president of the republic Indonesia issued the instruction of president number 5 in the year 2014 on a national movement about the program Anti-Sexual Crimes Against Children/ Gerakan Nasional Anti Kejahatan Seksual terhadap Anak (GN AKSA). these instructions aimed at, ministers attorney general. The police chief of the Republic of Indonesia, heads of non-ministerial government agencies as well as regional heads to undertake prevention of sexual violence case against children and involving all elements of society by proper duty, function, and authority. GN AKSA has rules to promotive and preventive measures to be put into action by the parents in the family. "Underwear Rules" program as strategy to protect their children from child sexual abuse. this strategy adopted child protection of the council of the European Union (Wahyuni, 2014). Underwear Rules can be used as a guide for the parents and teachers to discuss or communicate about sexuality. Underwear Rules has five essential principles known as PANTS; Private are Private; Always remember your body belongs to you; No means No; Talk about secret that upset you; speak up, someone can help (Salsabilah, 2017). This strategy was developed to improve the skills to protect themself (personal safety skill / PSS) from risk of child sexual violence. Education about "Underwear Rules" is necessary since early childhood.

Several neuroscience studies have shown that the first five years of life are periods of faster, more intense, and sensitive brain development to external or environmental influences. Children are prepared to enter the world of school. Sexual education for pre-school children, in addition to emphasizing sexual identity, is also on children's skills in protecting themselves from the risk of sexual crimes. For this reason, it is important to provide preschoolers with sexual education to protect themselves from the possibility of sexual crimes both at home and outside the home. It is to be noted that perpetrators of sexual violence do not only come from foreigners but can be from people known to the child, family, and even biological parents (Wahyuni, 2014).
Playing is the right method for conveying educational messages to preschoolers (Pratiwi, 2017). It is presumed that by playing the children will have fun so that they can better absorb the sex education messages that are conveyed. In this study, we made an educational game tool Busy Book and Snake and Ladder "Andara" to convey the message of the "Underwear Rules" program. Andara is taken from the names of three D3 nursing students from Bengkulu University, namely Andi, Da'yawati, and Ochtara.

Previous studies have shown that snakes ladders are effectively used as a medium for sexual education (Astuti, 2017). Meanwhile, the busy book is proven to be effective in increasing children's spatial-visual intelligence. The researcher was interested in using it to introduce the Underwear Rules program via the busy book. Previous research is still limited in comparing the most effective game tools for introducing PSS to preschoolers. This study aimed to compare the effectiveness of the Snakes Ladders game and the Busy Book "Andara" as an educational play tool in increasing preschool children's knowledge of Personal Safety skills (PSS) from the risk of child sexual abuse.

\section{METHODOLOGY}

Design: A quasi-experimental with a pretest-posttest control group design.

Sample: 107 preschool children of the age of three to six were taken by random sampling. They were divided into two groups, 54 pre-school for Snake Ladder group and 53 for Busy Book. Preschool with a mental or cognitive problem was excluded in this study.

Place: This study was conducted in the Bengkulu city, from November to December 2020. The author visited preschool both at home and at the Early Childhood Education School / Pendidikan Anak Usia Dini (PAUD). The schools that were visited are Raudhatul Athfal Al Azhar and PAUD IT AL Bunayya Bengkulu City.

Tool: Two educational games, Busy Book and Snake ladder "Andara" were made to convey the message of the "Underware Rules" program. Given the current pandemic period, the implementation of these two games is carried out by maintaining the Health protocol. Busy Book was played by only one preschool with the researcher. Meanwhile, the Snakes and Ladders were played by two children and guided by the researcher. The implementation of both games is 15 to 30 minutes. 
Data Collection and Data Analysis: Data of preschool's knowledge about personal Safety skills (PSS) from the risk of child sexual abuse were measured before and after playing snake ladder and Busy Book Andara. The data were collected using a questionnaire adapted from Aprilaz's questionnaire, 2016. The questionnaire consisted of 17 questions. Each question item contains the attitude that children take in protecting themselves when facing the risk of sexual violence (Aprilaz, 2016). This questionnaire uses the Guttman scale, for incorrect answers will be given a value of 0 and for correct answers given a value of 1 . The measurement results as a numeric $0-17$.

Data were analyzed using the SPSS version among 22 application. Univariate analysis was used to analyze respondent data and a description of the pre and postintervention children's knowledge. Meanwhile, for the bivariate analysis, the measurement data for the two groups were not homogeneous and not normally distributed. The results of the homogeneity test between the Busy Book intervention group and the Snakes Ladders obtained a Levene statistical signification value of 0.036 in the pre-intervention and $p=0.000$ in the postintervention, thus the data of the two groups were not homogeneous. For the Kolmogorov Smirnov normality test in both the pre and post-intervention groups, the results in the Busy Book intervention group obtained a significance value of 0.20 pre-intervention (normally distributed) while post-intervention obtained a signification value of 0.000 (not normally distributed). For the Snakes and Ladders intervention group, the preintervention significance value was 0.088 (normally distributed) and the post-intervention significance value was 0.000 (not normally distributed). Based on these results, to analyze the differences in pre and postintervention knowledge using the Wilcoxon test, while analyzing the difference in knowledge between the two interventions, Mann Whitney was tested.

\section{Validity and Reliability}

The validity test is done by comparing the $r$ table with $\mathrm{r}$ count at $n=20$ using the Pearson product-moment test with $\alpha=0.05$. Obtained $r$ count $>r$ table $(r$ table $=$ 0.444 ) but we improved the content for 3 question items. Reliability test with Cronbach's alpha test, and the results obtained $\alpha=0.730$ and $r$ table $0.444(n=20$, a significance level of $5 \%$ ) so that $\alpha>r$ tables means that the questionnaire was reliable or consistent.

\section{RESULTS}

The results of the univariate analysis of the characteristics of children showed that the mean age of the children was 4.69 years. As many as 58 people (54.21\%) of the study respondents were male. Based on the order of the children in siblings, the most respondents were the youngest as many as 36 people $(33.64 \%)$.

Table 1: Distribution of Respondents by Age, Gender and Order of Children in Siblings $(N=107)$

\begin{tabular}{|l|c|c|}
\hline $\begin{array}{c}\text { Characteristics of } \\
\text { Respondents }\end{array}$ & Min-Max & Mean \\
\hline \multicolumn{1}{|c|}{ Age } & $3-6$ & 4.69 \\
\hline $\begin{array}{c}\text { Characteristics of } \\
\text { Respondents }\end{array}$ & $\mathbf{N}$ & $\mathbf{\%}$ \\
\hline Sex & \multicolumn{2}{|c|}{} \\
\hline Male & 58 & 54.21 \\
Female & 49 & 45.79 \\
\hline Order of Children in Siblings \\
\hline Only one child & 23 & 21.50 \\
\hline Eldest & 26 & 24.30 \\
\hline Mid dle & 22 & 20.56 \\
\hline Youngest & 36 & 33.64 \\
\hline
\end{tabular}

Preschool's knowledge of Personal Safety Skill (PSS) against the risk for Child Sexual Abuse was assessed pre and post-intervention. In both interventions, there was an increase in the mean post-intervention, namely 13 for busy book and 14.91 for snakes' ladders. The results of the univariate test for each intervention can be seen in the following table:

Table 2: Description Preschool's Knowledge of Personal Safety Skill (PSS) against the Risk for Child Sexual Abuse

\begin{tabular}{|l|l|c|l|c|c|}
\hline Group & & N & Mean & $\begin{array}{c}\text { Standar d } \\
\text { Devia tion (SD) }\end{array}$ & Min-Max \\
\hline Busy & Pre-test & 53 & 11.30 & 3.451 & $5-17$ \\
\cline { 4 - 6 } Book & Post-test & & 13.00 & 5.818 & $4-17$ \\
\hline \multirow{2}{*}{$\begin{array}{l}\text { Snake } \\
\text { Ladder }\end{array}$} & Pre-test & 54 & 12.58 & 2.721 & $7-17$ \\
\cline { 4 - 6 } \cline { 4 - 5 } & Post- test & & 14.91 & 1.944 & $9-17$ \\
\hline
\end{tabular}

The results of differences in mean Preschool 's Knowledge of Personal Safety Skill (PSS) against the risk for Child Sexual Abuse in each group can be seen in the following table: 
Table 3: Differences in mean Preschool 's Knowledge of Personal Safety Skill (PSS) againts the Risk for Child Sexual Abuse in each group

\begin{tabular}{|l|c|c|c|c|c|c|c|c|}
\hline Group & $\mathbf{N}$ & & \multicolumn{3}{|c|}{ Mean Rank } & \multicolumn{2}{c|}{ Sum of Rank } & \multirow{2}{*}{ Sig } \\
\cline { 3 - 8 } & & $\begin{array}{c}\text { Negative } \\
\text { Ranks } \\
\text { /N }\end{array}$ & $\begin{array}{c}\text { Positive } \\
\text { Ranks } \\
/ \mathbf{N}\end{array}$ & $\begin{array}{c}\text { No. } \\
\text { (N) }\end{array}$ & $\begin{array}{c}\text { Negative } \\
\text { Ranks }\end{array}$ & $\begin{array}{c}\text { Positive } \\
\text { Ranks }\end{array}$ & \\
\hline $\begin{array}{l}\text { Busy } \\
\text { Book }\end{array}$ & 53 & Pre Test & $20.75 / 6$ & $23.35 / 39$ & 8 & 124.50 & 910.50 & 0.000 \\
\cline { 2 - 7 } & Post Test & & & & & & \\
\hline $\begin{array}{l}\text { Snake } \\
\text { Ladder }\end{array}$ & 54 & Pre Test & $8.50 / 5$ & $25.33 / 41$ & 8 & 42.50 & 1038.50 & 0.000 \\
\cline { 2 - 6 } & Post Test & & & & & & \\
\hline
\end{tabular}

Based on table 3, the results show that in the Busy Book intervention group there is a difference in the knowledge ranking of preschool children between pre and post-intervention, with a significance value of 0.000 . A total of 39 children experienced an increase in knowledge with an increase in the mean ranking of 910.50. The Snakes Ladders group also obtained a significance value of 0.000 and an increase in the mean ranking of 25.33 in 44 children with an increase in ranking of 1038.50. These results indicate that these two interventions have a significant effect on differences in preschool children's knowledge of Personal Safety Skill from the risk of pre and post-intervention sexual violence in each group.

Table 4: Differences in Mean Preschool 's Knowledge of Personal Safety Skill (PSS) Againts the Risk for Child Sexual Abuse Between Group Snake Ladder and Busy Book Andara

\begin{tabular}{|c|c|c|c|c|}
\hline Group & N & $\begin{array}{c}\text { Mean } \\
\text { Rank }\end{array}$ & Sum of Rank & \multirow{2}{*}{0.002} \\
\cline { 1 - 3 } $\begin{array}{c}\text { Busy } \\
\text { Book }\end{array}$ & 53 & 44.88 & 2378.50 & \\
\hline $\begin{array}{c}\text { Snake } \\
\text { Ladder }\end{array}$ & 54 & 62.95 & 3399.50 & \\
\hline
\end{tabular}

The results of the Mann-Whitney analysis in table 4 show that between the Busy Book and Snakes and Ladders intervention has a significant difference of 0.002 . The mean value in the Snakes Ladders group was higher than the Busy Book group, which was 62.95 with a total ranking of 3399.50. Thus it can be said that the Snakes Ladders intervention was more effective than the Busy Book.

\section{DISCUSSION}

The Difference in Increased Knowledge of Personal Safety Skills (PSS) Against Child Sexual Abuse in Preschool Before and After Playing Snake Ladder Andara
Sexual education using the snake ladder game in this study has a significant effect on increasing knowledge of skills to protect oneself from the risk of sexual violence (PSS) in preschool children. The Snakes Ladders game tool itself has been proven effective in several studies as an educational medium for both pre-school and high school children. Two previous studies have shown evidence that Snakes and Ladders are effective as a medium for sexual education even in children with intellectual disabilities (Rahayu, Marheni \& Purnomo, 2019; Handayani, Supena \& Rasmita, 2020). Also, snakes' ladders have been used on street children in Makassar City to assess children's ability to prevent sexual violence with a variety of ages ranging from 5 years to 11 years. The results show that children's abilities have increased significantly (Nurbaya \& Simon, 2019). Snakes and ladders are also effective in increasing children's knowledge at various age levels such as sexual education, thematic learning, dental health knowledge and knowledge about nutrition (Sara, Nurfianti \& Adriana, 2016; Chabib, Tri Djatmika \& Kuswandi, 2017).

In this study, 100 boxes of snakes were made with 9 ladders and 8 snakes. The ladder will give the correct answer to the PSS question while the snake will give the wrong answer to the PSS. those question which refers to the PANTS aspect.

The Difference in Increased Knowledge of Personal Safety Skills (PSS) Against Child Sexual Abuse in Preschool Before and After Playing Busy Book Andara

Providing knowledge to children about pre and the post-playing with the help of busy book also show significant influence. Busy book effective in improving reading skills, in improving count, vocabulary, the knowledge about transportation among preschool children (Nilmayani, Risma \& Zulkifli,, 2017; Mufliharsi, 2017; Ulfa \& Rahmah, 2017; Avirudini, 2018; Handayani and Anggraeni, 2020).

Busy Book Andara is a sexual education medium created to improve children's skills in protecting themselves so that they can avoid becoming victims of sexual violence. The name Andara was taken from the name of the D3 Nursing student at Unib who the creator of the busy book was Andi, Da'ya, and Ochtara. This busy book contains aspects of PANTS. the first page is the cover, on page 2 of the busy book, preschool is taught to dare to make decisions about which parts of 
their body should be touched, seen, and photographed (P) and which touch is good and which is not good (A). Furthermore, on page 3, the child is introduced to a suspicious condition that he may become a victim, namely when someone, whether they are known or not, invites them to a quiet place, the child is taught to dare to refuse and say he does not want to $(\mathrm{N})$. On pages 4 and 5 , children are taught to be willing to report and to anyone, they can report when things make them uncomfortable ( $\mathrm{T}$ and $\mathrm{S}$ ).

The Busy Book was made from flannel fabric consisting of 5 pages. Each page will represent a question in the questionnaire about skills to protect oneself from the risk of becoming a victim of sexual violence. Each page will tell a situation that describes the questions in the questionnaire. Here are the page details: Cover page Page 1 illustrates questions 1 and 2. On the sheet, a box will be provided containing the answer choices for the answer A will be represented by a thumbs-up image while answer B will be represented by a hand-drawn which will be glued to the space provided. Page 2 describes the situation for answering questions 3 to 10. Page 3 describes the situation for answering questions 9 to 12 . Page 4 describes the situation for answering questions 13 to 14 . Page 5 describes the situation for answering questions 15 to 17 .

The Difference in Increased Knowledge of Personal Safety Skills (PSS) Against Child Sexual Abuse in Preschool Between Group Snake Ladder and Busy Book Andara

The results of statistical tests show that the game of snakes and ladders is more effective than the Busy book in increasing children's knowledge of personal safety skills against the risk of child sexual abuse. Providing sexual education to children must indeed be adjusted to the stage of the child's age development. Thus, the message conveyed can be absorbed effectively by children. Preschoolers love to play. Through playing children have fun, can explore the environment, learn to socialize, and hone creativity (Ardiyanto, 2017).

To stimulate the desire to have fun learning in preschoolers, it is highly recommended to use pictorial media (Chen, 2020). Both educational play tools in this study present pictures that provide information about the skills that need to be taught to preschoolers in dealing with the risk of sexual crimes. Preschool children are introduced to the aspects contained in the "underwear rules" program. Children are introduced to sources of risk of sexual crimes that come not only from strangers but also from their close ones. Children are also taught to dare to reveal and report things that make them uncomfortable due to the perpetrator's actions.

Previous research has compared video media with playing with dolls in introducing Underwear Rules. The results obtained by both of them have effectiveness in increasing preschool children's knowledge about PSS (Aprilaz, 2016). Besides, the use of android which is growing rapidly and reaching almost all groups and ages can also be taken advantage of to introduce PSS to preschool children. Research on the development of educational games carried out on the Android platform made specifically for kindergarten and elementary school children has proven effective in increasing children's PSS knowledge (Oktavia, 2013). However, we still need to think about the negative effects of giving android/gadgets media at an early age. If the child has been addicted to gadgets, the risk of the child experiencing attention deficit disorder and hyperactivity is very likely (Setianingsih, Ardani \& Khayati, 2018). To minimize this effect, parents and educators must be able to choose a game tool for their children wisely and the importance of accompanying children when children play with gadgets.

Busy book for children must be played with adult guidance because on each sheet the parents will guide the child and provide instructions. Interaction and intimacy between children and adults, especially parents, will be created in this game. Through this activity, not only children can learn to prevent sexual violence, but adults who provide guidance also indirectly learn about the normal process of interaction and intimacy with children. The process of intimacy in the interaction between parents and children must run normally (IPCI), so that sexual crimes in the family can be prevented (Xie \& Miller, 2018).

Preschool children interact a lot with peers, this has a huge influence on gender socialization. Besides, preschoolers have a type of group game. Snakes and ladders can be played together with other friends. Meanwhile, during the busy book intervention, the children could only be interactive with the research team who guided the busy book game. At this age, they are learning to socialize. Playing with friends in addition to creating a fun atmosphere for children is also stimulated by competition. Snake and ladder media stimulate children to compete to reach the finish box. Through snakes and ladders, children are introduced 
interactively if they choose the wrong attitude to protect themselves from the risk of sexual violence, then they are forced to go down the bottom box. This experience spurs the child's memory of the educational messages conveyed through the Andara Snake Ladder.

At preschool, the people around the child greatly affect the child's ability in all things including sexual knowledge. Including the role of teachers, increasing the ability of teachers to develop children's skills to protect themselves against the risk of sexual violence is needed (Gansen, 2017; Martin et al., 2020). Preschool is symbolic / make believe play stage (2-7 years), children begin to absorb information in their environment through concrete objects with their rapidly developing imaginative abilities. Pattern divides the types of children's play according to activities that occur in children. At the age of 3 years, children still play alone, ignoring interaction activities. About 3 - 4 years old children start playing together in groups but there is no interaction between them, this stage is called Parallel Play. In associative games, children play in groups and there is already communication between them. Furthermore, at the age of 5 the child has started to the cooperative game stage where in the group there are rules for playing and division of tasks. The achievement of this stage is highly dependent on the stimulation of parents and teachers (Ardini \& Lestariningrum, 2018).

\section{Limitations}

This study did not analyze academic intelligence as a confounding factor that might have an effect on increasing preschool's knowledge of Personal Safety Skills (PSS) Against Child Sexual Abuse before and after sexual education with Snake Ladder and Busy Book Andara.

\section{CONCLUSION}

This study shows that Snakes and Ladders are more effective at increasing children's knowledge of personal safety skills from the risk of sexual violence than playing Busy Book.

\section{Recommendation}

Play tools that are interactive with peers and other people make it easier for children to take the educational messages in the media. For this reason, it is necessary to develop other educational games. Parents and teachers are the people close to the daily activities of children. So they need to improve their ability to deliver sexual education. Intimacy in interacting between parents or teachers and children affects children in absorbing learning.

\section{Conflict of Interests} interest.

The authors declare that they have no conflict of

\section{ACKNOWLEDGEMENT}

The author would like to thank the Association of Indonesian Nursing Vocational Education Institutions/ Asosiasi Institusi Pendidikan Vokasi Keperawatan Indonesia (AIPViKI) for funding in this study.

\section{REFERENCES}

Aprilaz, I. (2016). Perbandingan Efektivitas Antara Metode Video Dan Cerita Boneka Dalam Pendidikan Seksual Terhadap Pengetahuan Anak Prasekolah Tentang Personal Safety Skill. Retrieved from: http://repository. uinjkt.ac.id/dspace/bitstream/123456789/33035/1/Istiqomah Aprilaz-FKIK.pdf.

Ardini, P. P. \& Lestariningrum, A. (2018). Bermain dan Permainan Anak usia Dini (Sebuah kajian Teori dan Praktik). 1st edition, Kencana. $1^{\text {st }}$ Edition. Nganjuk, Jaw Timur: Adjie Media Nusantara.

Ardiyanto, A. (2017). Bermain Sebagai Sarana Pengembangan Kreativitas Anak Usia Dini. Jendela Olahraga, 2(2), pp $35-39$.

Arliman, L. (2017). Reformasi Penegakan Hukum Kekerasan Seksual Terhadap Anak Sebagai Bentuk Perlindungan Anak Berkelanjutan. Kanun Journal Ilmu Hukum, 19(2), pp 305-326.

Astuti, S.W. (2017). Pendidikan Seks pada Anak Taman Kanak-kanak Melalui Metode Permainan Ular Tangga "Aku Anak Berani”(Studi Deskripsi Komunikasi Interpersonal Anak dalam Bermain Ular Tangga “Aku Anak Berani”). Promedia, (2), pp 236-251. 
Avirudini, K. 2018). Pengembangan Media 3 Dimensi Busy Book Pada Tema Alat Transportasi Sub Tema MacamMacam Transportasi Di Tk Kelompok A Kartika Iv-92 Surabaya. Journal Mahasiswa Teknologi Pendidikan, 9(2), p. 1-7.

Chabib, M., Djatmika, E.T. \& Kuswandi, D. (2017). Efektivitas pengembangan media permainan ular tangga sebagai sarana belajar tematik SD. Journal Pendidikan: Teori, Penelitian, dan Pengembangan, 2(7), pp 910-918.

Chen, C. (2020). Analysis and Countermeasures of Current Situation of Sex Education for Children Aged 3-6. Lifelong Education, 9(7), pp 35-37.

Gansen, H. M. (2017). Reproducing (and Disrupting) Heteronormativity: Gendered Sexual Socialization in Preschool Classrooms. Sociology of Education, 90(3), pp 255-272.

Handayani, I. W. \& Anggraeni, A. (2020). Pengembangan Media Busy Book Tema Angka untuk Meningkatkan Penguasaan', Longda Xiokan. Journal of Mandarin Learning and Teaching. 3(1), pp 7-11.

Handayani, T., Supena, A. \& Rasmita, R. (2020). The Effectiveness of Snakes and Ladders Media on Sex Education for Children With Intellectual Disabilities. Journal Inovasi Pendidikan Dasar, 5(2), pp 71-80.

Kementerian Pemberdayaan Perempuan dan Perlindungan Anak (KPPPA) (KP3A) (2019). Profil Anak Indonesia Tahun 2019. Profil Anak Indonesia, p. 378. Retrieved from: https://www.kemenpppa.go.id/lib/uploads/slider/e56dc15242-profil-anak-indonesia_-2019.pdf.

Martin, J., Riazi, H., Firoozi, A. \& Nasiri, M. (2020). A sex education program for teachers of preschool children: a quasi-experimental study in Iran. BMC Public Health, 20, pp 1-9.

Mufliharsi, R. (2017). Pemanfaatan busy book pada kosakata anak usia dini di paud swadaya Pkk. Journal Metamorfosa, 5(2), pp 146-155.

Nilmayani, N., Risma, D. \& Zulkifli, N. (2017). Pengaruh Penggunaan Media Busy Book terhadap Kemampuan Membaca Permulaan Pada Anak Usia 5-6 Tahun di Paud Terpadu Filosofia Kubu Babussalam Rokan Hilir (Doctoral dissertation, Riau University).

Nurbaya, S. \& Simon, M. (2019). Pengaruh Penerapan Pendidikan Seks (Media Ular Tangga) Terhadap Kemampuan Pencegahan Kekerasan Seksual Pada Anak Jalanan Di Kampung Savana Kota Makassar. Journal of Islamic Nursing, 4(2), p. 60.

Oktavia, R. (2013). Identifying developmental levels and learning trajectories in statistics for grade 6-12 students.

Purnamawati, D. \& Haryati, S. (2020). Govt to facilitate rehabilitation of 305 child sexual abuse victims. ANTARA $2020,10^{\text {th }}$ July.

Pratiwi, W. (2017). Konsep Bermain Pada Anak Usia Dini. TADBIR: Journal Manajemen Pendidikan Islam, 5(2), pp $106-117$.

Rahayu, S.P., Marheni, E. \& Purnomo, E. (2019). Modification of Snakes and Ladder Games as Psychosexual Learning Media for Mentally Retarded. In International Conference of Mental Health, Neuroscience, and Cyber-psychology (pp. 121-127). Fakultas Ilmu Pendidikan.

Salsabila, S. (2017). Gambaran Tingkat Pengetahuan Orang Tua Tentang Program Underwear Rules dalam Pencegahan Kekerasan Seksual pada Anak Usia Prasekolah (Bachelor's thesis, UIN Syarif Hidayatullah Jakarta: Fakultas Kedokteran dan Ilmu Kesehatan, 2017).

Sara, P., Nurfianti, A. \& Adriana (2016). Efektifitas Metode Pendidikan Kesehatan Dengan Simulasi Permainan Ular Tangga Terhadap Perubahan Sikap Tentang Kesehatan Gigi dan Mulut Anak Usia Sekolah di SDN 03 Singkawang 
Tengah. Journal of Chemical Information and Modeling, 8(9), pp 1-58.

Setianingsih, Ardani, A. W. \& Khayati, F. N. (2018). Dampak Penggunaan Gadget Pada Anak Usia Prasekolah Dapat Meningkatan Resiko Gangguan Pemusatan Perhatian Dan Hiperaktivitas. Gaster, 16(2), p. 191.

Ulfah, A.A. \& Rahmah, E. (2017). Pembuatan dan pemanfaatan busy book dalam mempercepat kemampuan membaca untuk anak usia dini di paud budi luhur padang. Ilmu Informasi Perpustakaan dan Kearsipan, 6(1), pp 28-37.

Wahyuni, D. (2014). Gerakan Nasional Anti-Kejahatan Seksual. Info Singkat Kesejahteraan Sosial, VI(12), pp 9-12.

Xie, Q.-W. \& Miller, J. (2018). Perceptions of Intra-Familial Child Sexual Abuse and Intimate Parent-Child Interactions. Asian Social Work Journal, 3(2), pp 42-55. 